\title{
PEMBERANTASAN BUTA HURUF MELALUI ZONA LITERASI TERPADU DI DESA RAPAH OMBO
}

\author{
M. Bambang Edi Siswanto, Emy Yunita Rahma Pratiwi, Sayid Ma'rifatulloh, \\ Muhammad Nuruddin, Indah Mei Dwi Astuti \\ Universitas Hasyim Asy'ari Tebu Ireng Jombang \\ mbambangedi@gmail.com \\ emyyunita88@gmail.com \\ sayid.unhasy@gmail.com \\ indahmaidiastuti@gmail.com \\ rudin.moxer@mail
}

\begin{abstract}
Rapah Ombo Hamlet is one of the hamlets left behind in Jombang Regency, the lagging is caused by the lack of media for the progress of globalization that can be accessed by residents due to the lack of adequate electricity supply, the absence of mobile phone signals, as well as the far and difficult access roads leading to Rapah Ombo Hamlet. If measured, the distance from the center of Jombang to Rapah Ombo is about $35 \mathrm{Km}$ southwest and can be reached within 3 hours due to the difficulty of the terrain up and down along the steep limestone mountains. Economically, the Rapah Ombo sub-village consisting of 73 families can be said to be a prosperous hamlet with sufficient per capita income with a communal level of homogeneity to meet the daily needs of life. The majority of the people work as farmers and ranchers. Based on the observations, we can draw the conclusion that what is currently needed by the Rapah Ombo community is an increase in Human Resources (HR), especially the illiteracy eradication program by forming an integrated literacy zone, bearing in mind that there are still many people who cannot read and write. Departing from this fact, the problem of this study was how the implementation of the integrated literacy zone in Rapah Ombo was. This study result showed that the literacy eradication by implementing the integrated literacy zone was successful. It was proven by the increase of the number of the people who can read well.
\end{abstract}

Keywords: Rapah Ombo, Literacy Zone, Literacy Eradication

\begin{abstract}
Abstrak: Dusun Rapah Ombo merupakan salah satu dusun yang tertinggal di Kabupaten Jombang, ketertinggalan itu diakibatkan oleh tidak adanya media kemajuan globalisasi yang bisa diakses oleh warga yang disebabkan oleh tidak adanya suplay listrik yang mencukupi, tidak adanya sinyal telepon genggam, serta jauh dan sulitnya akses jalan menuju Dusun Rapah Ombo. Bila diukur, jarak dari pusat Kabupaten Jombang menuju Dusun Rapah Ombo sekitar $35 \mathrm{Km}$ arah barat daya dan dapat ditempuh dalam waktu 3 jam dikarenakan sulitnya medan naik turun menyusuri pegunungan kapur yang terjal. Secara ekonomi dusun Rapah Ombo yang terdiri dari 73 kepala keluarga bisa dikatakan dusun yang sejahtera dengan pendapatan per-kapita yang telah cukup dengan tingkat homogenitas yang komunal untuk memenuhi kebutuhan hidup sehari-hari. Mayoritas masyarakatnya berprofesi sebagai petani dan peternak. Berdasar hasil pengamatan yang telah kami lakukan, kami dapat menarik kesimpulan bahwa yang dibutuhkan saat ini oleh masyarakat Rapah Ombo adalah peningkatan Sumber Daya Manusia (SDM), terutama program pemberantasan buta huruf melalui metode pembentukan zona literasi terpadu, mengingat masih banyaknya warga yang kurang bisa membaca dan menulis. Berangkat dari kenyataan tersebut kami merumuskan permasalahan yang akan diungkap yaitu, bagaimanakah penerapan zona lliterasi terpadu, di dusun Rapah Ombo dalam pelaksanaan program ini. Dari hasil analisis menyatakan bahwa Pemberantasan Buta Huruf Melalui Pembentukan Zona Literasi Terpadu di Dusun Rapah Ombo Kabupaten Jombang dinyatakan berhasil. Dibuktikan dengan meningkanya jumlah masyarakat Rapah Ombo yang lihai dalam membaca.
\end{abstract}

Kata kunci: Rapah Ombo, Zona Literasi, Pemberantasan Buta Huruf 


\section{Pendahuluan}

Suatu usaha untuk meningkatkan sumber daya manusia dapat ditingkatkan dengan berbagai macam cara, yang salah satunya dapat ditingkatkan melalui pendidikan. "Pendidikan adalah suatu proses dalam rangka mempengaruhi siswa agar dapat menyesuaikan diri sebaik mungkin terhadap lingkungannya dan dengan demikian akan menimbulkan perubahan dalam dirinya yang memungkinkannya untuk berfungsi secara kuat dalam kehidupan masyarakat" (Oemar Hamalik, 2018: 79).

Sebagai kaum intelektual muda dan sebagai generasi penerus bangsa mahasiswa memiliki peran penting yaitu sebagai agen of change karena mahasiswa adalah orang yang seharusnya dapat membawa perubahanperubahan yang berdampak positif dan membangun dalam kehidupan masyarakat serta mampu menanamkan nilai-nilai positif terhadap masyarakat (Setiawan. 1:2016). Bila dirumuskan dalam peta peradaban, mahasiswa memiliki koordinat titik penentu sebagai subyek penggerak perubahan untuk kemajuan sebuah bangsa, sebagai suatu bagian masyarakat yang telah diberi rahmat oleh Allah Swt bisa mengeyam atau menikmati pendidikan formal yang lebih tinggi jika dibanding masyarakat pada umumnya. Kaum sarjana dan mahasiswa sudah sepatutnya mempertanyakan kepada diri sendiri tentang apa yang sudah diberikannya untuk kemaslahatan masyarakat sebagai pertanggungjawaban atas rahmat yang telah Allah SWT berikan. (Ndraha, Talizuduhu. 1987.45)

Seluruh kegiatan pendidikan, yakni berupa bimbingan, pengajaran dan pelatihan diarahkan untuk mencapai tujuan pendidikan. Tujuan pendidikan dikatakan tercapai apabila hasil belajar peserta didik mengalami perkembangan dan peningkatan (Achmad.2015:15) Perkembangan dan peningkatan dapat dicapai melalui kegiatan belajar. "Belajar adalah suatu proses usaha yang dilakukan seseorang untuk memperoleh suatu perubahan tingkah laku yang baru secara keseluruhan, sebagai hasil pengalamannya sendiri dalam interaksi dengan lingkungannya" (Slameto, 2017: 2).

Usaha untuk meningkatkan kemampuan calistung warga belajar yaitu dengan menumbuhkan inisiatif warga belajar untuk mengidentifikasi kebutuhan belajarmya, masalah, dan menentukan sumber belajar atau media yang digunakan untuk belajar dengan atau tanpa bantuan orang lain. Hal tersebut sesuai dengan pengertian sistem belajar mandiri. Dalam hal ini salah satunya warga belajar dapat memanfaatkan media belajar atau sumber belajar.

Zona Literasi Terpadu (ZLT) yang dalam pengelompokan Perpustakaan, Taman Bacaan Masyarakat tergolong dalam Perpustakaan Umum (public library). Dalam proses belajar, mengajar di semua jenjang pendididkan baik TK, SD, SMP, SMU, PERGURUAN TINGGI sekalipun dalam pendidikan formal, maupun non formal, para peneliti tidak lepas dari perpustakaan maupun Taman Bacaan Masyarakat, dari Taman Bacaan Masyarakat mereka akan memperoleh informasi tentang bermacammacam hal karena pada hakekatnya suatu Taman Bacaan Masyarakat adalah tempat berkumpulnya pengetahuan dari masa ke masa.

Kondisi sosial masyarakat Dusun Rapah Ombo masih tertinggal. Sebagai upaya pertanggungjawaban kami, kami mencoba membangun relasi dengan kawankawan karangtaruna Dusun Rapah Ombo, sebuah dusun kecil terdiri dari 73 kepala keluarga yang berada di sebuah lembah pegunungan kapur Kecamatan Plandaan Kabupaten Jombang. Berangkat dari pemaparan diatas, kami berkeinginan bershadaqah kepada Indonesia melalui berbagai kegiatan diantaranya, pembangunan pos literasi serta pemberantasan buta huruf di daerah-daerah terpencil dan keliling bakti budaya sebagai upaya untuk meneguhkan jati diri bangsa dalam konsep ndeder satriyo (Usman. 2018:42). 
Masa depan pada spektrum perjuangan jangka panjang sebagai bentuk tanggung jawab kami sebagai mahasiswa, sehingga melalui perjuangan yang panjang kami mengabdi untuk bangasa, lebih dari 2 bulan kami mendedikasikan untuk dusun rapah ombo,masyarakat merupakan gambaran peradapan dari sebuah bangsa yang besar. (Wahidmurni. 2015:43)

\section{Metode}

Untuk rancangan proses pemberantasan buta huruf, dalam rangka memenuhi indikator pencapaian berupa kemampuan masyarakat untuk membaca dan menulis, kami membuat rancangan proses pembelajaran dengan 4 tahap. Tahapan yang kami rumuskan ini adalah tahapan yang berdinamika dalam realitas di lapangan. Tahap pertama pengenalan alfabet, kedua pengenalan huruf vokal dan konsonan, ketiga pengenalan cara mengeja (membaca dan membaca lancar tanpa mengeja), keempat latihan menulis sederhana.

Untuk rancangan proses kegiatan pemberantasan buta huruf hijaiyah dengan tujuan masyarakat bisa membaca tulisan berhuruf hijaiyah kami menggunakan metode at-tartil karya Ustad Imam Syafi'i Fahrudin Sholeh dkk, yang membuat proses pembelajaran membaca dengan 6 tahapan yang diwujudkan dalam 6 jilid buku attartil.

Penelitian ini deskriptif kuantitatif memiliki 2 variabel yaitu variabel bebas $(\mathrm{X})$ adalah pemberantasan buta huruf dan variabel terikat $(\mathrm{Y})$ adalah motivasi belajar. (Arikunto, 2017:19)

Kegiatan penelitian ini direncanakan terlaksana selama dua bulan, bulan September sampai Oktober yang bertempat di Desa rapak ombo, Kabupaten Jombang yang meliputi kegiatan observasi, prapelaksanaan, pelaksanaan, evaluasi, praktik, dan penyusunan laporan.

\section{Hasil dan Pembahasan}

Bagian ini menyajikan hasil penelitian dan pembahasan dalam satu kesatuan. Dari hasil analisis menyatakan bahwa Pemberantasan Buta Huruf Melalui Pembentukan Zona Literasi Terpadu di Dusun Rapah Ombo berhasil. Dengan kata lain terdapat pengaruh Zona Literasi Terpadu dalam menuntaskan buta huruf di Dusun Rapah Ombo Kabupaten Jombang.

a. Alasan masih banyak kejadian buta huruf di dusun Rapah Ombo

1) Semakin tinggi kemiskinan biasanya tingkat buta aksaranya juga tinggi.

2) Kedua yakni lokasinya yang tidak terjangkau. Mereka jauh dari perkembangan informasi dan teknologi.

3) Mereka yang di pelosok biasanya hanya bisa menggunakan bahasa minim. Lantaran jauh dari perkembangan teknologi dan informasi dan disibukan dengan pemenuhan kebutuhan primer, motivasi belajar mereka yang buta huruf, sangat rendah.

b. Alasan masih banyak kejadian buta huruf di dusun Rapah Ombo

1) Semakin tinggi kemiskinan biasanya tingkat buta aksaranya juga tinggi.

2) Kedua yakni lokasinya yang tidak terjangkau. Mereka jauh dari perkembangan informasi dan teknologi.

3) Mereka yang di pelosok biasanya hanya bisa menggunakan bahasa minim. Lantaran jauh dari perkembangan teknologi dan informasi dan disibukan dengan pemenuhan kebutuhan primer, motivasi belajar mereka yang buta huruf, sangat rendah.

Dalam proses pembelajaran masih sering terjadi penundaan jadwal belajar, hal itu disebabkan banyak warga yang memiliki motivasi belajar yang sangat rendah sehingga tidak menepati jadwal pembelajaran yang sudah ditetapkan. Banyak warga belajar yang tidak mau 
datang kalau tidak dijemput oleh tutornya sendiri, ada yang malu untuk ikut kegiatan belajar, ada yang dengan alasan banyak pekerjaan sehingga mereka mengurungkan niatnya untuk belajar bahkan ada yang memang malas untuk ikut belajar.

Hambatan yang paling dirasakan yaitu ketidakmampuan warga dalam mengikuti proses pembelajaran sehigga secara kualitas masih ada yang belum optimal dalam menguasai materi pembelajaran. Tindak lanjut yang dilakukan oleh penyelenggara adalah melakukan program jaring garap. Program ini bertujuan untuk membelajarkan kembali para warga belajar yang belum mampu menguasai materi pembelajaran.

Setelah proses belajar telah berakhir maka para warga belajar yang sudah lulus tes memperoleh Surat Keterangan Melek A ksara (SUKMA) I. Bagi mereka yang sudah memper oleh sertifikat tersebut kemudian berhak ikut program pemberantasan buta aksara tahap kedua yang lamanya juga 3 bulan. Apabila lulus tahap kedua ini, maka warga diberi sertifikat SUKMA II. Setelah tahap kedua lulus maka warga belajar berhak mengikuti tahap ketiga yang lamanya 3 bulan. Apabila tahap ketiga lulus akan diberi sertifikat SUKMA III. Jika sudah memperoleh sertifikat SUKMA III maka bisa direkomendasikan untuk mengikuti ujian paket A setara SD sehingga bagi yang lulus akan memperoleh sertifikat/ijazah setara SD.

\section{c. Strategi penerapan program pembentukan zona literasi terpadu di dusun Rapah Ombo}

Pelaksanaan kegiatan dilakukan dengan memerhatikan prinsip-prinsip pembelajaran pendidikan keaksaraan sebagaimana yang dinyatakan oleh Hiryanto (2009), yaitu:

1) Konteks lokal, yaitu dengan mempertimbang kan minat dan kebutuhan masyarakat, agama, budaya, bahasa dan potensi lingkungan;

2) Desain lokal, yaitu proses pembelajaran yang merupakan respon (tanggapan) minat dan kebutuhan masyarakat yang dirancang sesuai dengan situasi dan kondisi masyarakat dusun Rapah Ombo;

3) Proses partisipatif, yaitu proses pembelajaran yang melibatkan peserta secara aktif; dan

4) Fungsional hasil belajar, yaitu hasil belajarnya dapat meningkatkan pengetahuan, kemampuan dan sikap positif dalam rangka meningkatkan mutu dan taraf hidup masyarakat.

Target kegiatan selama kegiatan, diharapkan minimal 55 peserta sudah melek huruf dengan asumsi bahwa jangka waktu yang tersedia terbatas. Namun demikian, program ini akan dilaksanakan secara berkelanjutan agar buta aksara benar-benar terberantas sempurna dan masyarakat dapat melek huruf secara permanen.

Metode pembelajaran yang diterapkan dalam kegiatan ini adalah metode yang menitik beratkan pada keaktifan peserta, namun pembelajaran dilakukan dengan tim pelaksana sebagai pembawa materi. Setelah materi, peserta kemudian diberi kegiatan untuk aktif berlatih dengan pendampingan dari tim sebagai fasilitator. Tindakan yang dilakukan dalam program ini dimulai dengan melakukan pretest untuk mengetahui kemampuan awal peserta, yaitu kemampuan membaca, menulis, dan berhitung. Selanjutnya dilakukan pembelajaran huruf dan angka yang mengacu pada modul yang disusun oleh tim pelaksana dalam tiga tahapan dan setiap tahapan pembelajaran tersebut selalu diikuti dengan evaluasi untuk mengetahui perkembangan kemajuan aksara peserta. Kegiatan terakhir adalah melakukan post test, yaitu tes terakhir yang dilakukan untuk mengetahui tingkat perkembangan keaksaraan peserta setelah semua proses pembelajaran.

Sebelum memulai kegiatan pembelajaran dilakukan sosialisasi ke rumah-rumah penduduk ataupun ke tempat kerja seperti kebun, ladang, dan sawah untuk memperkenalkan program yang akan 
dijalankan. Data yang diperoleh berupa jumlah peserta yang mampu membaca, menulis, dan berhitung di setiap tahapan dihitung dengan membandingkan jumlah peserta yang belum bisa membaca baca, menulis, dan berhitung di ketiga tahapan. Persentase peserta yang mampu membaca, menulis, dan berhitung kemudian dianalisis untuk menentukan tingkat keberhasilan program.

\section{d. Pentingnya program pemberantasan buta huruf bagi masyarakat dusun Rapah Ombo}

Buta huruf merupakan salah satu faktor yang menghambat kualitas sumber daya manusia. Salah satu hal mendasar yang harus dipenuhi untuk meningkatkan kualitas sumber daya manusia adalah pemberantasan buta huruf di kalangan masyarakat. Tujuan dari kegiatan pengabdiaan ini adalah untuk meningkatkan kemampuan aksara masyarakat sekitar hutan di Desa Rapah Ombo, memiliki sumber daya alam yang melimpah, seperti kayu dan hasil hutan bukan kayu. Selain itu, daerah ini juga relatif terisolasi yang disebabkan oleh aksesibilitasnya sulit, dengan demikian warga jadi sulit mengakses pendidikan sehingga angka buta huruf cukup tinggi.

Pemberantasan buta huruf disusun bekerja sama dengan Pusat Kegiatan Belajar Bersama Masyarakat (PKBM) Harapan Bersama dan sebuah Lembaga Swadaya Masyarakat (LSM) yang fokus pada kegiatan pemberantasan buta aksara. Kemampuan aksara masyarakat sebelum dan sesudah program ini diukur melalui pre test dan post test. Usia peserta yang ikut dalam kegiatan ini adalah 17-59 tahun dengan total 55 peserta. Program dibagi menjadi tiga tahap, -yaitu tahap membaca, menulis, dan menghitung. Setiap tahapan mengacu pada modul pengajaran yang disusun oleh tim pelaksana dan dilakukan dengan menggunakan metode yang menarik. Hasilnya menunjukkan bahwa kemampuan membaca peserta meningkat dari 11 menjadi 70 , kemampuan menulis meningkat dari 9 menjadi 70, sedangkan untuk kemampuan berhitung meningkat dari 15 menjadi 71 .

\section{e. Hasil yang diperoleh saat pelaksanaan program ini}

Data kemampuan belajar membaca dapat ditunjukkan pada Tabel 1 di bawah ini:

Tabel 1. Kemampuan Belajar Membaca Dusun Rapah Ombo Kabupaten Jombang

\begin{tabular}{|l|c|}
\hline \multicolumn{1}{|c|}{ Kegiatan } & Hasil \\
\hline Pre test & $11 \%$ \\
\hline Belajar Membaca Tahap 1 & $23 \%$ \\
\hline Belajar Membaca Tahap 2 & $52 \%$ \\
\hline Belajar Membaca Tahap 3 & $65 \%$ \\
\hline Post test & $85 \%$ \\
\hline
\end{tabular}

Kemampuan belajar membaca dibagi dalam tiga tahapan, yaitu belajar membaca tahap 1, 2, dan 3. Berdasarkan pre test sebesar $11 \%$ atau 6 orang yang mampu membaca dari 55 orang peserta. Setelah mengikuti pembelajaran membaca tahap 1 , dilakukan evaluasi tahap pertama dimana peserta yang mampu membaca meningkat menjadi $23 \%$ atau 13 orang dibandingkan pada pre test. Pada evaluasi tahap kedua terjadi peningkatan jumlah peserta yang mampu membaca meningkat menjadi $52 \%$ atau 28 orang, dan evaluasi tahap ketiga meningkat menjadi $65 \%$ atau 35 orang peserta dapat membaca dan pada post test terjadi peningkatan sebesar $85 \%$ atau 53 orang dari jumlah peserta yang sudah bisa membaca.

Kompetensi program Pemberantasan Buta Aksara yaitu:

1. Menulis.

Warga belajar harus mampu mengenal huruf dan menyalin tulisan yang dibuat oleh tutor.

2. Membaca.

Warga belajar harus mampu mengenal hu ruf dan merangkai huruf menjadi kata.

3. Berhitung.

Warga belajar harus mampu mengenal an gka satuan, puluhan, ratusan, dan ribuan.

Dari hasil analisis menyatakan bahwa Pemberantasan Buta Huruf Melalui Pembentukan Zona Literasi Terpadu di 
Dusun Rapah Ombo Kabupaten Jombang. Kemampuan Membaca Belajar membaca dibagi dalam tiga tahapan, yaitu belajar membaca tahap 1, 2, dan 3. Berdasarkan pre test sebesar 11 atau 6 orang yang mampu membaca dari 55 orang peserta. Setelah mengikuti pembelajaran membaca tahap 1 , dilakukan evaluasi tahap pertama dimana peserta yang mampu membaca meningkat menjadi $23 \%$ atau 13 orang dibandingkan pada pre test. Pada evaluasi tahap kedua terjadi peningkatan jumlah peserta yang mampu membaca meningkat menjadi $52 \%$ atau 28 orang, dan evaluasi tahap ketiga meningkat menjadi $65 \%$ atau 35 orang peserta dapat

membaca dan pada post test terjadi peningkatan sebesar $70 \%$ atau 38 orang dari jumlah peserta yang sudah bisa membaca.

Kemampuan Menulis Berdasarkan pre test sebesar $9 \square$ atau 5 orang yang mampu menulis dari 55 orang peserta. Setelah mengikuti pembelajaran menulis tahap 1, dilakukan evaluasi tahap pertama, yaitu peserta yang mampu menulis meningkat menjadi 25 atau 13 orang dibandingkan pada pre test. Pada evaluasi tahap kedua terjadi peningkatan jumlah peserta yang mampu menulis sebesar 40 atau 22 orang, dan evaluasi tahap ketiga sebesar $69 \%$ atau 37 orang peserta dapat menulis dan pada post test terjadi peningkatan sebesar 70 atau 38 orang dari jumlah peserta yang sudah bisa menulis.

Kemampuan berhitung berdasarkan pre test sebesar 15 atau 8 orang yang mampu berhitung dari total jumlah 55 orang peserta. Setelah mengikuti pembelajaran berhitung tahap 1, dilakukan evaluasi tahap pertama, yaitu peserta yang mampu berhitung meningkat menjadi 30 atau 16 orang dibandingkan pada pre test. Pada evaluasi tahap kedua terjadi peningkatan jumlah peserta yang mampu berhitung sebesar 50 atau 27 orang, dan evaluasi tahap ketiga sebesar 68 atau 37 orang peserta dapat berhitung dan pada post test terjadi peningkatan sebesar 71atau 39 orang dari jumlah peserta yang sudah bisa berhitung pengaruh yang cukup berarti dalam memotivasi peserta, meningkatkan kesiapan belajar, meningkatkan kemampuan calistung (baca, tulis, dan hitung) dan komunikasi, serta meningkatkan kecakapan fungsional (misalnya membaca KTP, menulis nama, dan membuat kalimat sederhana

$$
\text { Konsep pembangunan manusia }
$$
adalah memperluas pilihan manusia, terutama untuk memenuhi kebutuhan dasar seperti kesehatan, pendidikan, dan kemampuan daya beli. Dengan demikian, suatu daerah dengan kualitas pembangunan manusia yang baik idealnya memiliki persentase penduduk miskin yang rendah (IPM 2007). Menurut Samuelson dan Nordhaus (1997), penyebab dan terjadinya penduduk miskin di negara yang berpenghasilan rendah adalah karena dua hal pokok, yaitu rendahnya tingkat kesehatan dan gizi dan lambatnya perbaikan mutu pendidikan. Oleh karena itu, upaya pertama yang harus dilakukan pemerintah adalah melakukan pemberantasan penyakit, perbaikan kesehatan dan gizi, perbaikan mutu pendidikan, pemberantasan buta huruf, dan peningkatan keterampilan penduduknya. Kelima hal itu adalah upaya untuk memperbaiki kualitas Sumber Daya Manusia (SDM).

Apabila hal-hal tersebut dapat dilakukan dengan segera, maka penduduk dapat menggunakan modal dengan lebih efektif, menyerap teknologi baru, dan belajar dari kesalahannya. Apabila ini ditunjang dengan penyediaan fasilitas umum yang memadai, maka akan segera dapat mengentaskan kemiskinan. Oleh karena itu, tingkat pendidikan (termasuk keterampilan), tingkat kesehatan yang rendah dan terbatasnya fasilitas umum merupakan penyebab dari adanya kemiskinan. termasuk yang berdomisili di sekitar hutan dan lokasinya sulit diakses.

\section{Simpulan}

Penelitian ini bertujuan untuk mengetahui faktor penyebab mengapa masih banyak kejadian buta huruf di dusun Rapah 
Ombo dan untuk mengetahui bagaimanakah penerapan program pembentukan zona literasi terpadu di dusun Rapah Ombo.

Selain itu juga untuk mengetahui seberapa pentingkah program pemberantasan buta huruf bagi masyarakat dusun Rapah Ombo dan untuk mengetahui kendala apa saja yang dialami saat proses pelaksanaan program ini.

Melihat kondisi Dusun Rapah Ombo yang demikian, kami berpendapat bahwa yang dibutuhkan di Dusun Rapah Ombo adalah

1. Peningkatan sumber daya manusia dan pengiriman bantuan-bantuan materi maupun finansial.

2. Perlu di berdayakan kegiatan yang serupa dengan Zona Literasi Terpadu agar semakin meningkat kemampuan masyarakat dalam berliterasi.

3. Perlu adanya keterlibatan para akademisi dalam mengabdikan keilmuannya terlebih di daerah yang minus pendidikan Besar pengaruh dari keberadaan Zona Literasi Terpadu sebagai media belajar sistem belajar mandiri terhadap kemampuan belajar warga belajar buta aksara

\section{Daftar Pustaka}

Achmad Rifa'i dan Chatarina Tri Anni. (2015). Psikologi Pendidikan. Semarang: UPT UNNES.

Arikunto, Suharsimi. (2017). Prosedur Penelitian Suatu Pendekatan Praktek. Jakarta : Rineka Cipta.

Dimyati dan Mudjiono. (2009). Belajar dan Pembelajaran. Jakarta: PT Rineka Cipta.

Hamalik, Oemar. (2018). Proses Belajar Mengajar. Jakarta: PT Bumi Aksara.

Ndraha, Talizuduhu. (1987). Pembangunan Masyarakat, Mempersiapkan Masyarakat Tinggal Landas. Jakarta: PT. Bina Aksara.

Sugiyono. (2010). Metode Penelitian Pendidikan. Bandung: Alfabeta.

Slameto. (2017). Pemberdayaan Masyarakat Perdesaan. Jakarta: Rosda.
Setiawan. (2016). Nilai Moral Masyarakat. Jakarta: PT Bina Aksara

Usman, Moh Uzer dan Lilis Setiawati. (2018). Upaya Optimalisasi Kegiatan Belajar Mengajar. Bandung: Remaja Rosdakarya.

Wahidmurni, Alifin Mustikawan, dan Ali Ridho. (2015). Evaluasi Pembelajaran: Kompetensi dan Praktik. Yogyakarta: Nuha Letera. 